The Agriculturists 16(2): 43-57 (2018) ISSN 2304-7321 (Online), ISSN 1729-5211 (Print)

A Scientific Journal of Krishi Foundation

Indexed Journal

DOI: http://dx.doi.org/ 10.3329/agric.v16i02.40342

Impact Factor: 0.568 (GIF, 2015)

\title{
Nutrients Content in Some Vegetables Grown in South-Central Coastal Regions of Bangladesh
}

\author{
AKM. Faruk-E-Azam ${ }^{1}$, Md. Taifur Rahman ${ }^{2}$, Muhammad Maniruzzaman ${ }^{1}$, Abdullah-Al- \\ Zabir $^{1}$, Md. Nizam Uddin ${ }^{1}$ \\ ${ }^{1}$ Department of Agricultural Chemistry, Patuakhali Science and Technology University, Dumki, \\ Patuakhali-8602, Bangladesh, ${ }^{2}$ Agriculture and Fisheries Division, A Public Trust Under the Ministry \\ of Water Resource, Gulshan-1, Dhaka, Bangladesh \\ *Corresponding author and Email: alzabir361@gmail.com
}

Received: 15 October 2018

Accepted: 25 December 2018

\begin{abstract}
Soil salinity is one of the most important abiotic stresses for crop production. A study was conducted to analyze the relationship between salinity level and nutrient contents in some popular vegetables grown in some selected tidal areas of Barguna and Patuakhali districts of Bangladesh. Samples of six different vegetables such as bottle gourd leaf (Lagenaria siceraria), sweet gourd leaf (Cucurbita maxima), radish leaf (Raphanus sativus), bean (Lablab niger), red amaranth (Amaranthus gangeticus) and spinach (Spinacia oleracea) were collected along with soils from different locations of the study areas and were analyzed for phosphorus $(\mathrm{P})$, potassium $(\mathrm{K})$, calcium $(\mathrm{Ca})$, magnesium $(\mathrm{Mg})$, sulphur (S) contents. Soil $\mathrm{pH}$ and electrical conductivity (EC) were determined. In saline areas, comparatively lower amounts of $\mathrm{P}, \mathrm{K}, \mathrm{Ca}, \mathrm{Mg}$ and $\mathrm{S}$ were detected in most of the collected vegetables than those of non-saline areas. Conversely, bottle gourd leaf, radish leaf and bean accumulated comparatively higher amount of $\mathrm{Ca}$ at higher salinity levels. The uptake of $\mathrm{P}$ by bottle gourd leaf and radish leaf, $\mathrm{Mg}$ by bottle gourd leaf and red amaranth was also higher in the saline soil. The inconsistent uptake of $\mathrm{Ca}, \mathrm{Mg}$ and $\mathrm{P}$ were found in some vegetables due to the differences of fertilizer application and intercultural operation. The vegetables could tolerate moderate soil salinity (soil EC up to7.9 $\mathrm{dSm}^{-1}$ ) and might be recommended to grow in the tidal saline areas of Barguna and Patuakhali districts of Bangladesh.
\end{abstract}

Keywords: Salinity, vegetables, tidal area, nutrient contents.

\section{Introduction}

Vegetables are good sources of vitamins and minerals. However, in south central part of Bangladesh, the vegetables are not grown sufficiently to meet up the demand. Efforts should be made to grow vegetables in coastal area by selecting suitable vegetable crops. Indigenous vegetables are rich in vitamins and minerals. The harvest of these vegetables mainly depends on soil and water management, fertilizer application, cultural practices and controlling pest and diseases.

Salinity causes not only social and health problems for rural population but also creates unfavorable environment and hydrological situations that restrict normal crop production. It decreases agricultural production through a lack of fresh irrigation water and soil degradation. In 
general, soil salinity is believed to be mainly responsible for low land use as well as lower cropping intensity in the coastal area (Rahman and Ahsan, 2001).

The salinity causes yield loss up to $50 \%$ of different vegetables (Marcelis and Hooijdonk, 1999). The amount of yield loss differs for different vegetables but threshold salinity level is specific for each vegetable. It is reported that due to salinity the yield loss of beans and radish was up to $10 \%$ at EC 1.5 and $2.0 \mathrm{dSm}^{-1}$, the loss was $25 \%$ and $50 \%$ at EC 2.30, 3.0 and 3.60, $8.0 \mathrm{dSm}^{-}$ 1 , respectively (Marcelis and Hooijdonk, 1999). The yield of spinach and tomato show the sensitivity to salinity and their yield loss was up to $50 \%$ at EC 8.0 and $7.60 \mathrm{dSm}^{-1}$ (Tanji, 1990).

Plant performance, usually expressed as a crop yield, plant biomass or crop quality, may be adversely affected by salinity-induced nutritional disorders. These disorders may result from the effect of salinity on nutrient availability, competitive uptake, transport or partitioning within the plant. Salinity dominated by $\mathrm{Na}$ salts not only reduces $\mathrm{Ca}^{2+}$ availability but reduces its transport and mobility to growing regions of the plant, affecting the quality of both vegetative and reproductive organs (Grattan and Grieve, 1999). These disorders are aggravated in environments with high transpiration demands. Salinity can directly affect nutrient uptake such as excess $\mathrm{Na}$ in soil solution may reduce $\mathrm{K}$ uptake, and $\mathrm{Cl}^{-}$ may reduce $\mathrm{NO}_{3}{ }^{-}$uptake (Prakash et al., 2010).

The occurrence of these disorders and the ultimate effect on crop yield or quality depends on the crop species and the growing environment. Nonetheless, salinity can cause a combination of complex interactions that affect plant metabolism. In several studies it has been shown that salinity increases the internal requirement for a particular nutrient such as $\mathrm{P}$ in tomato and $\mathrm{K}$ in spinach (Talbi et al., 2011). In a study Grattan and Grieve (1994) showed that salinity caused deficiency of a specific element in plants that have lower cellular tolerance for a specific ion. Moreover, it is reasonable to believe that numerous salinity-nutrient interactions are occurring at the same time but whether they ultimately affect crop yield or quality depends upon the salinity level and composition of salts, the crop species and a number of environmental factors (Grattan and Grieve, 1999).

Salt tolerance of a crop is usually considered in terms of plant growth over a range of electrical conductivity (EC). Selection of salt tolerant vegetable species is very important for the growers, as because the cash value of vegetable is usually higher than that of field crops. However, there is a little or no useful information available on saline tolerant vegetables, and there is an obvious need for strengthening research on this direction (Shannon and Grieve, 1999).

A vast area of the southern coastal region of Bangladesh is affected by salinity of different degrees. . Cropping intensity is low and the people living there are also deprived of nutritional food. Salt tolerant vegetables should be identified and adopted for cultivation for the nutritional security of the people therein (Rahman et al., 2008). It is well known that there is a direct relationship between soil salinity and nutrient contents in the plant. Nonetheless, the maintenance of a balance in plant nutrient content may be an indicator of salinity tolerance of the crops. Therefore, the present study was undertaken to analyze the relationship between soil salinity levels and plant nutrient contents in some vegetables grown in the coastal area of Bangladesh.

\section{Materials and Methods}

\subsection{Sampling sites}

Vegetable and soils were collected randomly during December 2013 to January 2014 from four areas of Patuakhali and three areas of Barguna district (Table 1). Twenty nine samples of 6 different vegetables such as bottle gourd leaf (Lagenaria siceraria), sweet gourd leaf (Cucurbita maxima), radish leaf (Raphanus sativus), bean (Lablab niger), red amaranth 
(Amaranthus gangeticus) and spinach (Spinacia oleracea) and soil from each vegetable field were collected. The samples were brought to the laboratory, processed and preserved accordingly.

\subsection{Analytical Methods for soil and vegetable samples}

2.2.1 Soil pH and Electrical conductivity (EC) $\mathrm{pH}$ of the soil samples was determined by glass electrode $\mathrm{pH}$ meter as described by Ghosh et al., (1983) and Jackson, (1962). The electrical conductivity of the collected soil samples was determined electrometrically (1:2.5; soil: water) by a conductivity meter as described by Anderson and Ingram, (1996) and Tandon, (1995). Both determinations were done in the Laboratory of Agricultural Chemistry, PSTU.

\subsubsection{Determination of phosphorus,} potassium, calcium, magnesium and sulphur

All the plant samples were digested with di-acid mixture at $180^{\circ} \mathrm{C}$, filtered through filter paper (Whatman No. 42) and stored in suitable containers. Available soil phosphorus was extracted by Olsen's method (Olsen et al., 1954). The phosphorus in soils and vegetables were determined as described by Jackson, (1973) with the help of a spectrophotometer at $660 \mathrm{~nm}$ wave length colorimetrically using $\mathrm{SnCl}_{2}$ as reductant. Potassium content in vegetables and exchangeable potassium in soils were determined with the help of flame emission spectrophotometer using potassium filter (Ghosh et al., 1983; APHA, 2005). Calcium and magnesium in the samples were determined by complexometric method of titration using $\mathrm{Na}_{2}-$ EDTA as a complexing agent according to Page et al., (1982) and APHA, (2005). Sulphur was determined by turbidimetric method with the help of a spectrophotometer set at $420 \mathrm{~nm}$ wave lengths as in Page et al., (1982).

\subsection{Statistical analysis}

The statistical analyses of the data obtained from chemical analyses of vegetables and soil samples were performed using Excel Statistics version 4.0 as described by Gomez and Gomez (1984).

\section{Results and Discussion}

\subsection{Soil physicochemical properties}

Different sampling areas showed different $\mathrm{pH}$ and EC Values. The highest $\mathrm{pH}$ (7.9) and EC $\left(5.7 \mathrm{dSm}^{-1}\right)$ was observed in Sonakata and the lowest $\mathrm{pH}$ (5.2) and EC (1.19 dS m $\left.{ }^{-1}\right)$ was observed in Nilgonj and Kadamtala, respectively (Table 2).

Table 1. Information regarding soil and vegetable sampling sites of Barguna and Patuakhali districts of Bangladesh

\begin{tabular}{lll}
\hline & Location & \multicolumn{1}{c}{ Vegetables } \\
\hline \multirow{4}{*}{ Saline } & $\begin{array}{l}\text { Sonakata, Taltoli, Barguna } \\
\text { (Outside the embankment) }\end{array}$ & $\begin{array}{l}\text { Bottle gourd leaf, sweet gourd leaf, } \\
\text { bean, red amaranth }\end{array}$ \\
\cline { 2 - 3 } & $\begin{array}{l}\text { Sonakata, Taltoli, Barguna } \\
\text { (inside the embankment) }\end{array}$ & $\begin{array}{l}\text { Bottle gourd leaf, sweet gourd leaf, } \\
\text { radish leaf, bean, spinach }\end{array}$ \\
\cline { 2 - 3 } Nisanbari, Taltoli, Barguna & Red amaranth, spinach \\
\hline \multirow{3}{*}{ Non-saline } & Latachapli, Kuakata, Patuakhali & $\begin{array}{l}\text { Bottle gourd leaf, radish leaf, bean, red } \\
\text { amaranth, spinach }\end{array}$ \\
\cline { 2 - 3 } & Panjupara, Kuakata, Patuakhali & $\begin{array}{l}\text { Bottle gourd leaf, sweet gourd leaf, } \\
\text { bean, red amaranth, spinach }\end{array}$ \\
\cline { 2 - 3 } & Nilgonj, Khepupara, Patuakhali & $\begin{array}{l}\text { Bottle gourd leaf, bean, red amaranth } \\
\text { Kadamtala, Dumki, Patuakhali }\end{array}$ \\
\cline { 2 - 3 } & $\begin{array}{l}\text { Bottle gourd leaf, sweet gourd leaf, } \\
\text { bean, red amaranth, spinach }\end{array}$ \\
\hline
\end{tabular}


Table 2. $\mathrm{pH}, \mathrm{EC}$ and ionic constituents of $\mathrm{P}, \mathrm{K}, \mathrm{Ca}, \mathrm{Mg}$ and $\mathrm{S}$ of different soils of vegetable field at Patuakhali and Barguna districts

\begin{tabular}{|c|c|c|c|c|c|c|c|c|}
\hline \multirow{2}{*}{$\begin{array}{l}\text { SL } \\
\text { No. }\end{array}$} & \multirow[b]{2}{*}{ Locations } & \multirow{2}{*}{$\begin{array}{l}\text { Soil } \\
\text { pH }\end{array}$} & \multirow{2}{*}{$\begin{array}{l}\text { Soil } \\
\text { EC } \\
\left(\mathrm{dSm}^{-1}\right)\end{array}$} & $\mathbf{P}$ & $\mathbf{K}$ & Ca & Mg & $\mathbf{S}$ \\
\hline & & & & \multicolumn{5}{|c|}{$\mu g^{-1}$} \\
\hline 01. & Sonakata (outside) & 7.5 & 7.73 & 27.93 & 159.9 & 1700.0 & 570.0 & 106.85 \\
\hline 02. & Sonakata (inside) & 7.9 & 5.7 & 08.32 & 171.6 & 1624.0 & 752.4 & 68.92 \\
\hline 03. & Nisanbari & 7.9 & 4.3 & 11.77 & 210.6 & 1628.0 & 573.6 & 80.98 \\
\hline 04. & Latachapli & 6.5 & 1.71 & 10.45 & 74.1 & 356.0 & 126.0 & 41.84 \\
\hline 05 . & Panjupara & 6.6 & 0.86 & 18.07 & 85.8 & 408.0 & 146.4 & 09.70 \\
\hline 06. & Nilgonj & 5.2 & 1.23 & 21.91 & 144.3 & 230.0 & 769.2 & 103.29 \\
\hline 07. & Kadamtala & 7.2 & 1.19 & 27.86 & 198.9 & 214.0 & 188.4 & 27.01 \\
\hline \multicolumn{2}{|c|}{ Range } & $\begin{array}{l}5.2- \\
7.9\end{array}$ & $\begin{array}{l}0.86- \\
7.73\end{array}$ & $\begin{array}{l}8.32- \\
27.93\end{array}$ & $\begin{array}{l}74.1- \\
210.6\end{array}$ & $\begin{array}{l}214.0- \\
1700.0\end{array}$ & $\begin{array}{l}126.0- \\
769.2\end{array}$ & $\begin{array}{l}9.70- \\
106.85\end{array}$ \\
\hline \multicolumn{2}{|c|}{ Mean } & - & - & 18.04 & 149.31 & 880.00 & 446.57 & 62.66 \\
\hline \multicolumn{2}{|c|}{ SD value } & - & - & 8.17 & 52.50 & 724.44 & 285.34 & 37.61 \\
\hline \multicolumn{2}{|c|}{ CV\% } & - & - & 45.29 & 35.16 & 82.32 & 63.90 & 60.01 \\
\hline
\end{tabular}

\subsection{Soil Nutrient Status}

The limits of $\mathrm{P}$ and $\mathrm{K}$ ranged from 8.32-27.93 $\mathrm{mgKg}^{-1}$ and 74.1-210.6 $\mu \mathrm{g} \mathrm{g}^{-1}$. The maximum $\mathrm{P}$ and $\mathrm{K}$ were estimated in soil at Sonakata, Taltoly, Barguna outside the embankment and Nisanbari. The lowest $\mathrm{P}$ and $\mathrm{K}$ were present in soil at Sonakata, Taltoly, Barguna inside the embankment and Nisanbari Taltoly, Barguna, respectively. The limits of $\mathrm{Ca}, \mathrm{Mg}$ and $\mathrm{S}$ ranged from 214.0-1700.0, 126.0-769.2 and 9.70-106.85 $\mu \mathrm{g} \mathrm{g}^{-1}$, respectively. The maximum $\mathrm{Ca}$ and $\mathrm{S}$ were estimated in soil at Sonakata, Taltoly, Barguna inside and $\mathrm{Mg}$ was the highest in Nilgonj. The lowest $\mathrm{Ca}, \mathrm{Mg}$ and $\mathrm{S}$ was present in soil at Kadamtala, Latachapli and Panjupara, respectively (Table 2). Saline soil naturally contains higher amount of $\mathrm{Ca}, \mathrm{Mg}$ and $\mathrm{S}$ (Donald, 2003). Evidences showed that P can also be the dominating element in saline soils. This might be the main cause of exalted concentrations of these elements at higher soil EC levels.

\subsection{The mineral compositions ( $\mathrm{P}, \mathrm{K}, \mathrm{Ca}, \mathrm{Mg}$ and $S$ status) of bottle gourd leaf}

The limits of $\mathrm{P}$ and $\mathrm{K}$ ranged from 2243.592564.10 and 70.0-95.0 $\mu \mathrm{g} \mathrm{g}^{-1}$. The maximum $\mathrm{P}$ and $\mathrm{K}$ was estimated in bottle gourd leaf at
Sonakata, Taltoly, Barguna (EC $7.73 \mathrm{dSm}^{-1}$ ) and Panjupara, Kuakata, Patuakhali $\left(\mathrm{EC} 0.86 \mathrm{dSm}^{-1}\right)$, respectively. The lowest $\mathrm{P}$ and $\mathrm{K}$ was present in bottle gourd leaf at Kadamtala, Dumki, Patuakhali (EC $1.19 \mathrm{dSm}^{-1}$ ) and Sonakata, Taltoli, Barguna (EC $7.73 \mathrm{dSm}^{-1}$ ) (Figure 1 and 2). The limits of $\mathrm{Ca}, \mathrm{Mg}$ and $\mathrm{S}$ ranged from 9949.9-29498.8, 8946.7-28394.1 and 690-990 $\mu \mathrm{g}$ $\mathrm{g}^{-1}$, respectively. The maximum $\mathrm{Ca}$ and $\mathrm{Mg}$ was estimated in bottle gourd leaf of Sonakata, Taltoly, Barguna (EC $7.73 \mathrm{dSm}^{-1}$ ) and $\mathrm{S}$ was detected at Panjupara, Kuakata, Patuakhali (EC $0.86 \mathrm{dSm}^{-1}$ ). The lowest $\mathrm{Ca}, \mathrm{Mg}$ and $\mathrm{S}$ was present in bottle gourd (leaf) collected from Kadamtala, Dumki, Patuakhali (EC 1.19 dSm$^{-1}$ ) (Figure 2 and 3).

The concentrations of soil $\mathrm{Ca}$ and $\mathrm{Mg}$ were increased with the increase of soil EC levels (Figure 4 and Table 2). The concentration of $\mathrm{S}$ and $\mathrm{P}$ fluctuated randomly with different EC levels and uptake of S and P in bottle gourd leaf was high at locations where $S$ and $P$ concentrations in soil were high (Figure $2 \&$ Table 2). The K concentration was the highest at lower EC level and randomly oscillates at the highest to medium EC level. The uptake of $\mathrm{K}$ in bottle gourd leaf was increased with the increase 
of $\mathrm{K}$ concentration in soil (Figure $1 \&$ Table 2), which might have occurred due to the reactions of soil with nutrients and fertilizer application.
High concentrations of substrate $\mathrm{Ca}^{2+}$ often result in increased leaf-Ca along with a marked reduction in leaf-Mg (Bernstein, 1962).

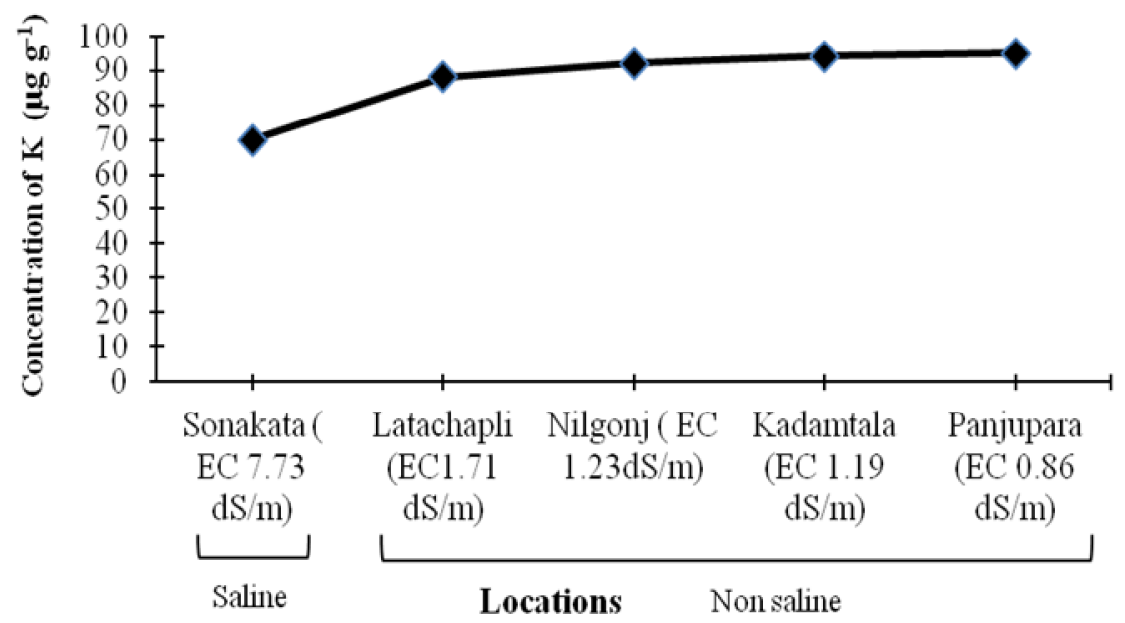

Figure 1. Concentrations of $\mathrm{K}$ in bottle gourd leaf at different EC levels of Barguna and Patuakhali districts.

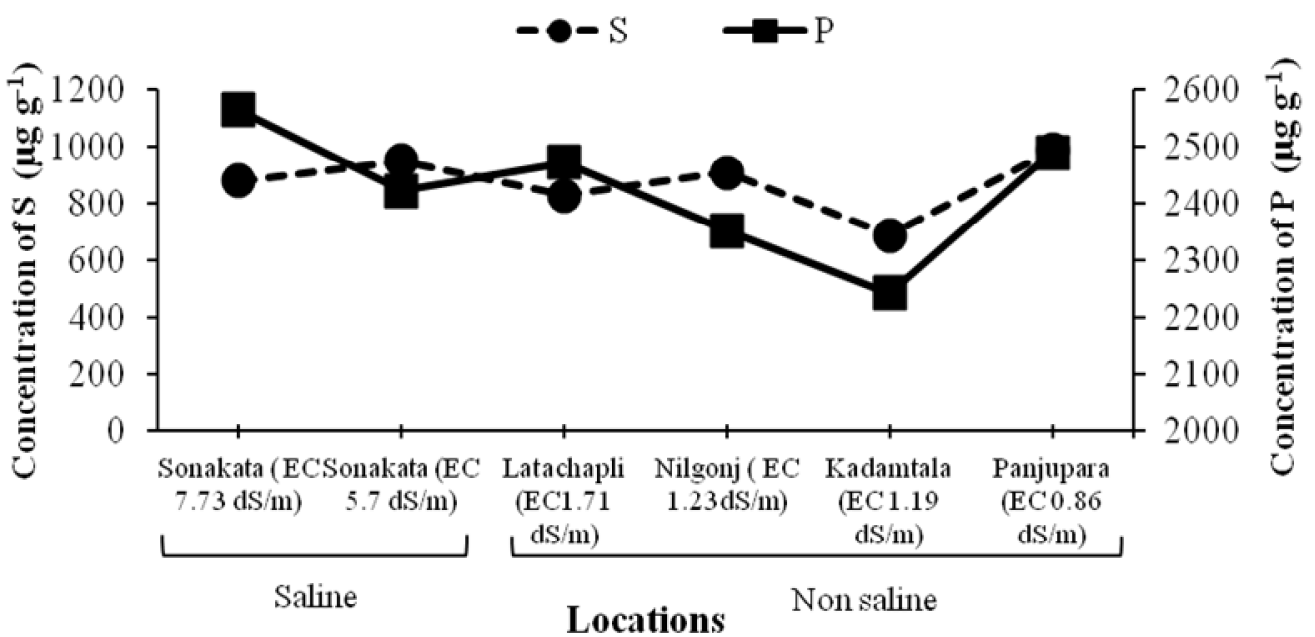

Figure 2. Concentrations of $S$ and $P$ in bottle gourd leaf at different EC levels of Barguna and Patuakhali districts. 


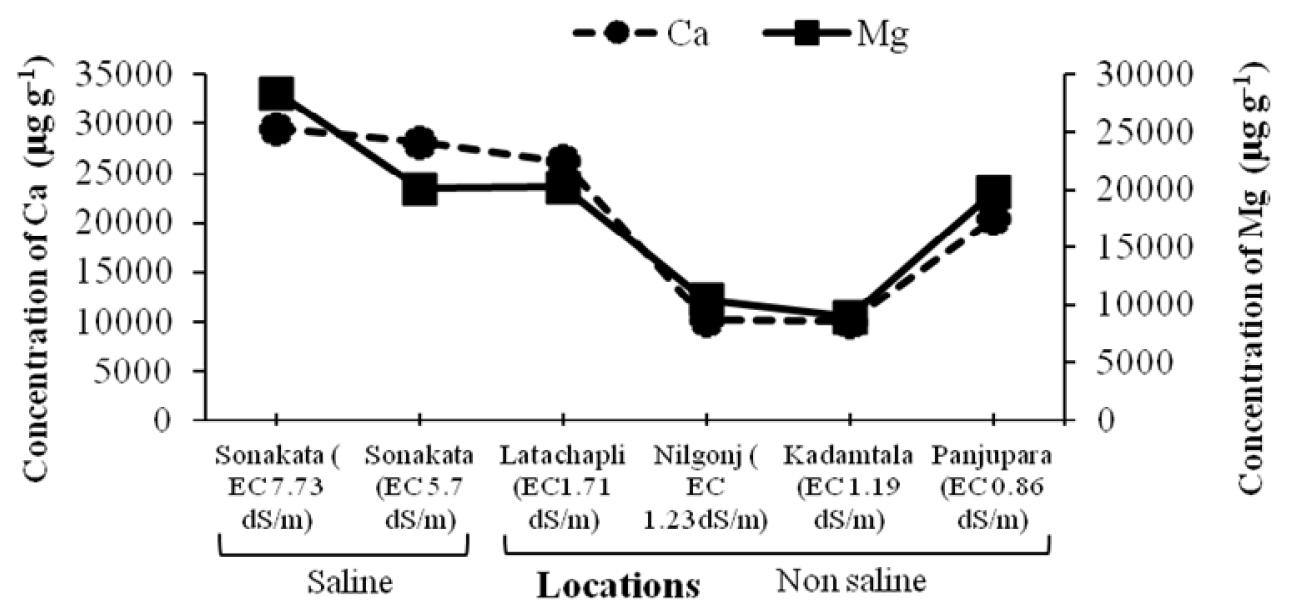

Figure 3. Concentrations of $\mathrm{Ca}$ and $\mathrm{Mg}$ in bottle gourd leaf at different EC levels of Barguna and Patuakhali districts.

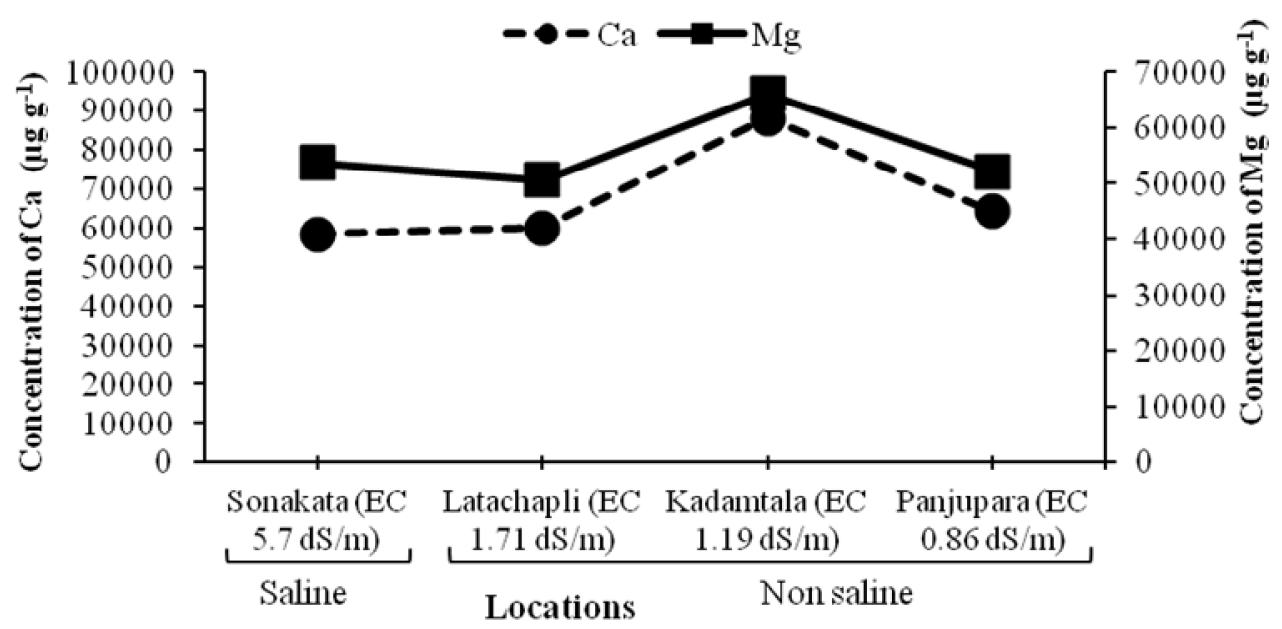

Figure 4. Concentrations of $\mathrm{Ca}$ and $\mathrm{Mg}$ in sweet gourd leaf at different EC levels of Barguna and Patuakhali districts.

3.4 The mineral compositions $(\mathrm{P}, \mathrm{K}, \mathrm{Ca}, \mathrm{Mg}$ and $S$ status) of sweet gourd leaf

The limits of $\mathrm{P}$ and $\mathrm{K}$ ranged from 3205.133846.15 and 57.0-108.0 $\mu \mathrm{g} \mathrm{g}^{-1}$. The maximum $\mathrm{P}$ and $\mathrm{K}$ was estimated in Sweet gourd leaf at Kadamtala, Dumki, Patuakhali (EC 1.19 dSm$^{-1}$ ) and Latachapli (EC $1.71 \mathrm{dSm}^{-1}$ ), respectively. The lowest $\mathrm{P}$ and $\mathrm{K}$ was present in Sweet gourd leaf of Sonakata, Taltoly and Barguna (EC 5.70 $\mathrm{dSm}^{-1}$ ) (Figure 5 and 6). The limits of $\mathrm{Ca}, \mathrm{Mg}$ and $\mathrm{S}$ ranged from 58356.5-88176.0, 50557.266123.2 and $860.0-1330.0 \mu \mathrm{g} \mathrm{g}^{-1}$. The maximum 
$\mathrm{Ca}$ and $\mathrm{Mg}$ was estimated in Sweet gourd leaf of Kadamtala, Dumki and Patuakhali (EC 1.19 $\mathrm{dSm}^{-1}$ ) and $\mathrm{S}$ was present at Latachapli (EC $1.71 \mathrm{dSm}^{-1}$ ). The lowest $\mathrm{Ca}$ and $\mathrm{S}$ was present in Sweet gourd leaf of Sonakata (EC $5.70 \mathrm{dSm}^{-1}$ ) and $\mathrm{Mg}$ was the lowest at Latachapli (EC 1.71 $\mathrm{dSm}^{-1}$ ) (Figure 4 and 5).

It was observed that the concentrations of $\mathrm{P}, \mathrm{K}$, $\mathrm{Ca}, \mathrm{Mg}$ and $\mathrm{S}$ in sweet gourd leaf were found higher at lower EC level of soil. Therefore, salinity reduced the uptake of $\mathrm{P}, \mathrm{K}, \mathrm{Ca}, \mathrm{Mg}$ and $\mathrm{S}$ in sweet gourd leaf and their concentrations were increased simultaneously with the concentration present in soil. Concentrations of $\mathrm{Ca}$ and $\mathrm{Mg}$ exhibited almost the same trend throughout the study area (Figure 4, 5 and 6 and Table 2), which might be happened due to the fertilizer application and availability of plant nutrients.

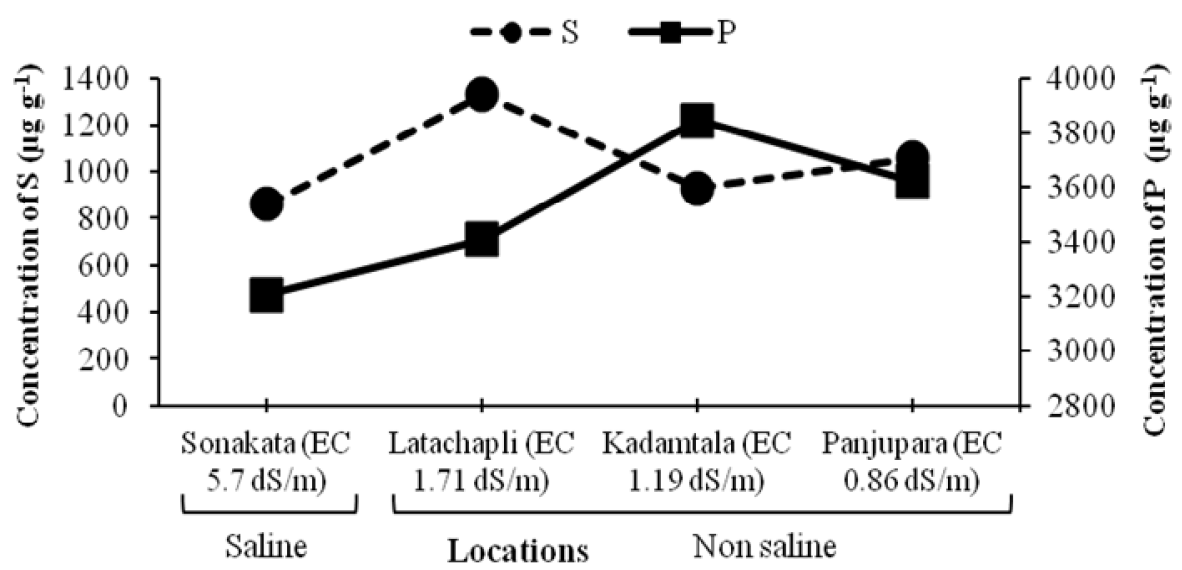

Figure 5. Concentrations of $S$ and $P$ in sweet gourd leaf at different EC levels of Barguna and Patuakhali districts.

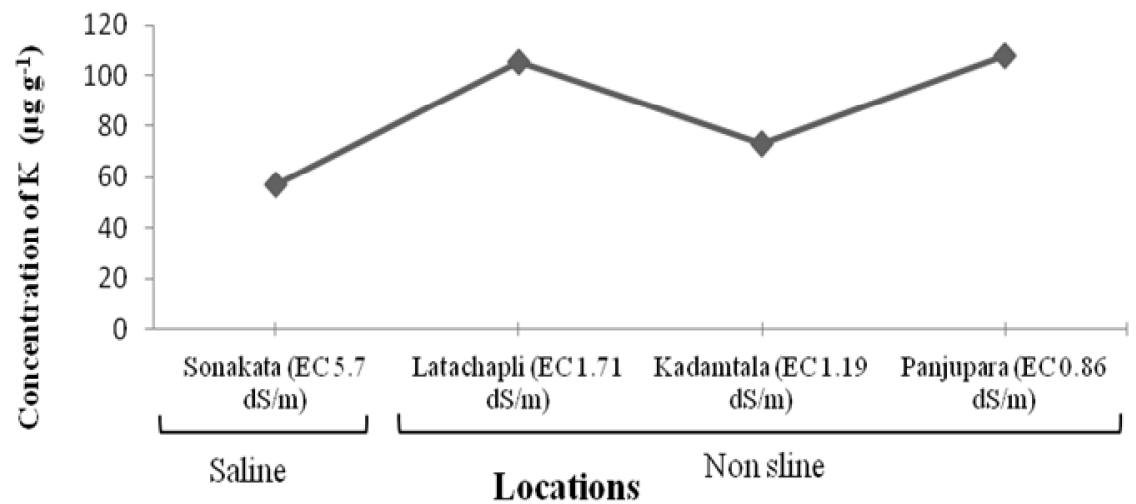

Figure 6. Concentrations of $\mathrm{K}$ in sweet gourd leaf at different EC levels of Barguna and Patuakhali districts. 


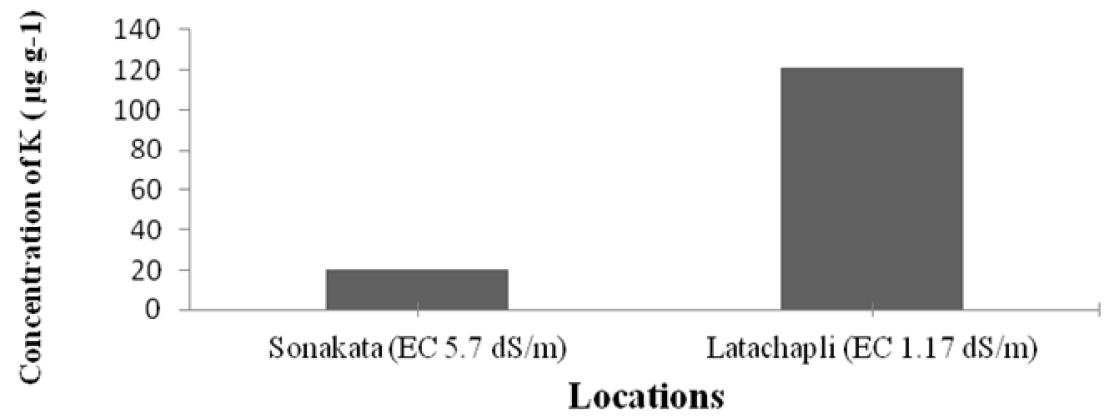

Figure 7. Concentrations of $\mathrm{K}$ in radish leaf at different $\mathrm{EC}$ levels of Barguna and Patuakhali districts.

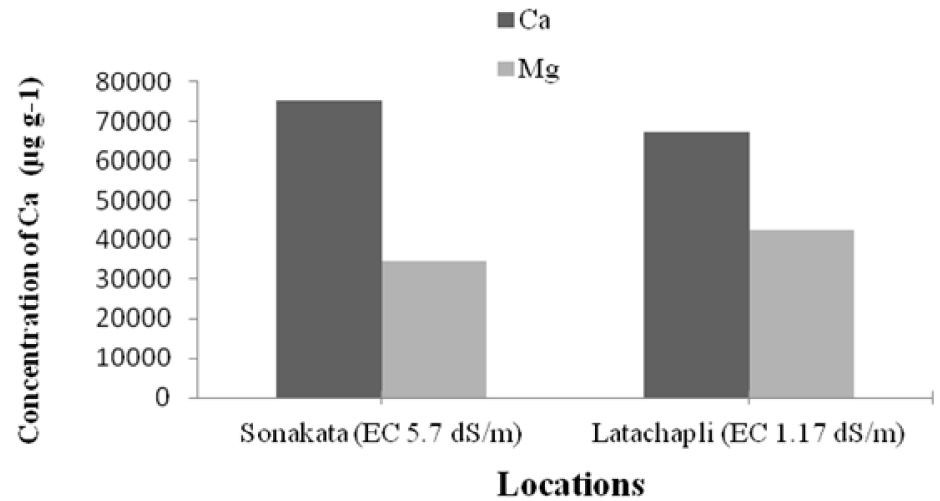

Figure 8. Concentrations of $\mathrm{Ca}$ and $\mathrm{Mg}$ in radish leaf at different EC levels of Barguna and Patuakhali districts.

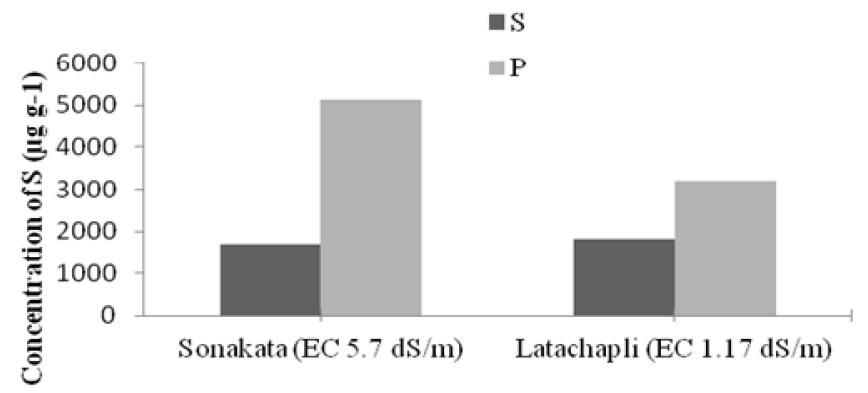

Locations

Figure 9. Concentrations of $\mathrm{S}$ and $\mathrm{P}$ in radish leaf at different EC levels of Barguna and Patuakhali districts. 


\subsection{The mineral compositions (P, K, Ca, Mg and $S$ status) of radish leaf}

The limits of $\mathrm{P}$ and $\mathrm{K}$ ranged from 3205.125128.21 and 20.0-121.0 $\mathrm{\mu g} \mathrm{g}^{-1}$ (Figure 7 and 9). The maximum $\mathrm{P}$ and $\mathrm{K}$ was estimated in Radish leaf collected from Sonakata, Taltoly and Barguna (EC $5.70 \mathrm{dSm}^{-1}$ ) and Latachapli, Kuakata and Patuakhali (EC $1.71 \mathrm{dSm}^{-1}$ ), respectively. The maximum $\mathrm{Mg}$ and $\mathrm{S}$ was estimated in radish leaf of Latachapli, Kuakata and Patuakhali (EC $1.71 \mathrm{dSm}^{-1}$ ) and $\mathrm{Ca}$ was present at Sonakata, Taltoly and Barguna (EC $5.70 \mathrm{dSm}^{-1}$ ) (Figure 8 and 9).

The concentrations of $\mathrm{K}, \mathrm{Mg}$ and $\mathrm{S}$ were higher at lower EC level. Therefore, salinity reduced the uptake of $\mathrm{K}, \mathrm{Mg}$ and $\mathrm{S}$ in radish leaf. In a study of Mor and Manchanda (1992) it was found that chloride-salinity reduced the sulphur content in the straw of pea. The uptake of $\mathrm{Ca}$ and $\mathrm{P}$ was increased at higher EC levels. Calcium content of Sonakata soil (EC $5.7 \mathrm{dSm}^{-1}$ ) was about 4.5 times higher than that of Latachapli soil (EC $\left.1.71 \mathrm{dSm}^{-1}\right)$. For this, accumulation of $\mathrm{Ca}$ in radish leaf increased at Sonakata. Though $\mathrm{P}$ content of Sonakata soil $\left(8.32 \mu \mathrm{g} \mathrm{g}^{-1}\right.$ at EC 5.7 $\mathrm{dSm}^{-1}$ ) was less than that of Latachapli soil (10.45 $\mathrm{g} \mathrm{g} \mathrm{g}^{-1}$ at EC $\left.1.71 \mathrm{dSm}^{-1}\right)$, its accumulation in radish leaf was higher at Sonakata (Figure 8, 9 and Table 2). The findings of the study asserted that soil salinity enhanced the internal requirement of radish plant for $\mathrm{P}$ as stated by Grattan and Grieve, (1999).

\subsection{The mineral compositions $(\mathrm{P}, \mathrm{K}, \mathrm{Ca}, \mathrm{Mg}$ and $S$ status) of bean}

The limits of $\mathrm{P}$ and $\mathrm{K}$ ranged from 3525.64 4487.18 and 52.0-76.0 $\mu \mathrm{g} \mathrm{g}^{-1}$, respectively The maximum $\mathrm{P}$ and $\mathrm{K}$ was estimated in bean at Kadamtala, Dumki, and Patuakhali (EC 1.19 $\mathrm{dSm}^{-1}$ ), and Sonakata, Taltoly, and Barguna (EC $\left.7.73 \mathrm{dSm}^{-1}\right)$, respectively. The lowest $\mathrm{P}$ and $\mathrm{K}$ was present in bean at Sonakata, Taltoly, and Barguna (EC $7.73 \mathrm{dSm}^{-1}$ ) and Latachapli, Kuakata, and Patuakhali (EC $1.71 \mathrm{dSm}^{-1}$ ), respectively (Figure 10 and 12). The contents of $\mathrm{Ca}, \mathrm{Mg}$ and $\mathrm{S}$ ranged from 11222.4 - 23406.7, $12057.7-10112.9$ and $820.0-990.0 \mu \mathrm{g} \mathrm{g} \mathrm{g}^{-1}$, respectively The maximum $\mathrm{Ca}$ and $\mathrm{S}$ was estimated in bean at Sonakata, Taltoly, and Barguna (EC $7.73 \mathrm{dSm}^{-1}$ ) and $\mathrm{Mg}$ was present at Kadamtala, Dumki, and Patuakhali (EC 1.19 $\left.\mathrm{dSm}^{-1}\right)$. The lowest $\mathrm{Ca}$ was present in bean at Kadamtala, Dumki, and Patuakhali (EC 1.19 $\left.\mathrm{dSm}^{-1}\right) ; \mathrm{Mg}$ was present at Sonakata, Taltoly, and Barguna (EC $7.73 \mathrm{dSm}^{-1}$ ) and $\mathrm{S}$ was present at Latachapli, Kuakata, and Patuakhali (EC $1.71 \mathrm{dSm}^{-1}$ ) (Figure 11 and 12).

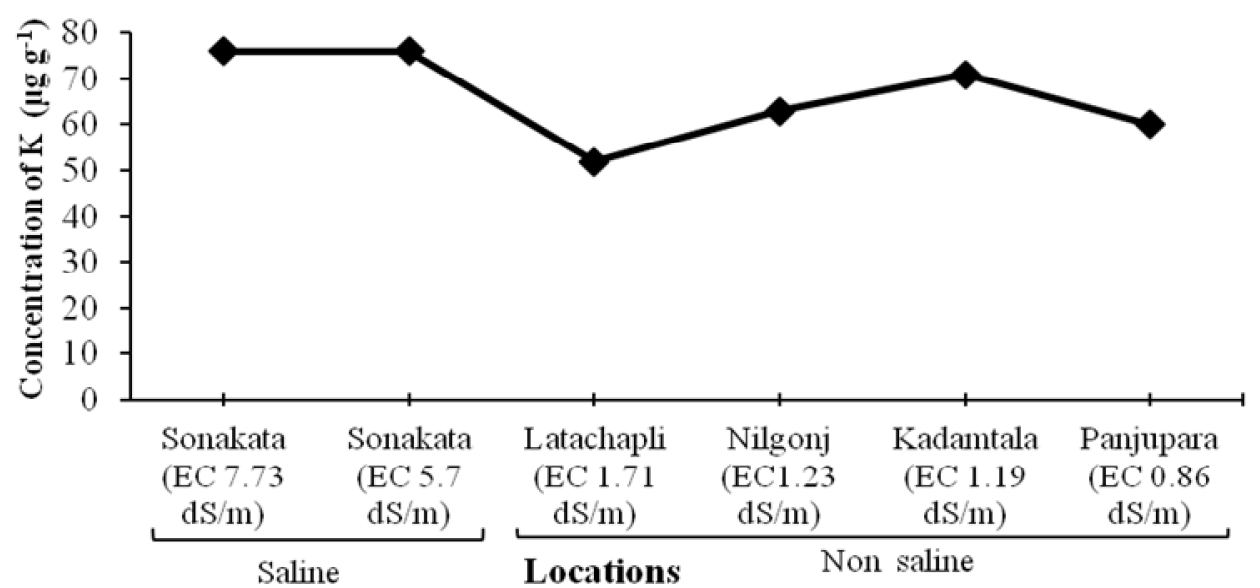

Figure 10. Concentration of $\mathrm{K}$ in bean at different EC levels of Barguna and Patuakhali districts. 


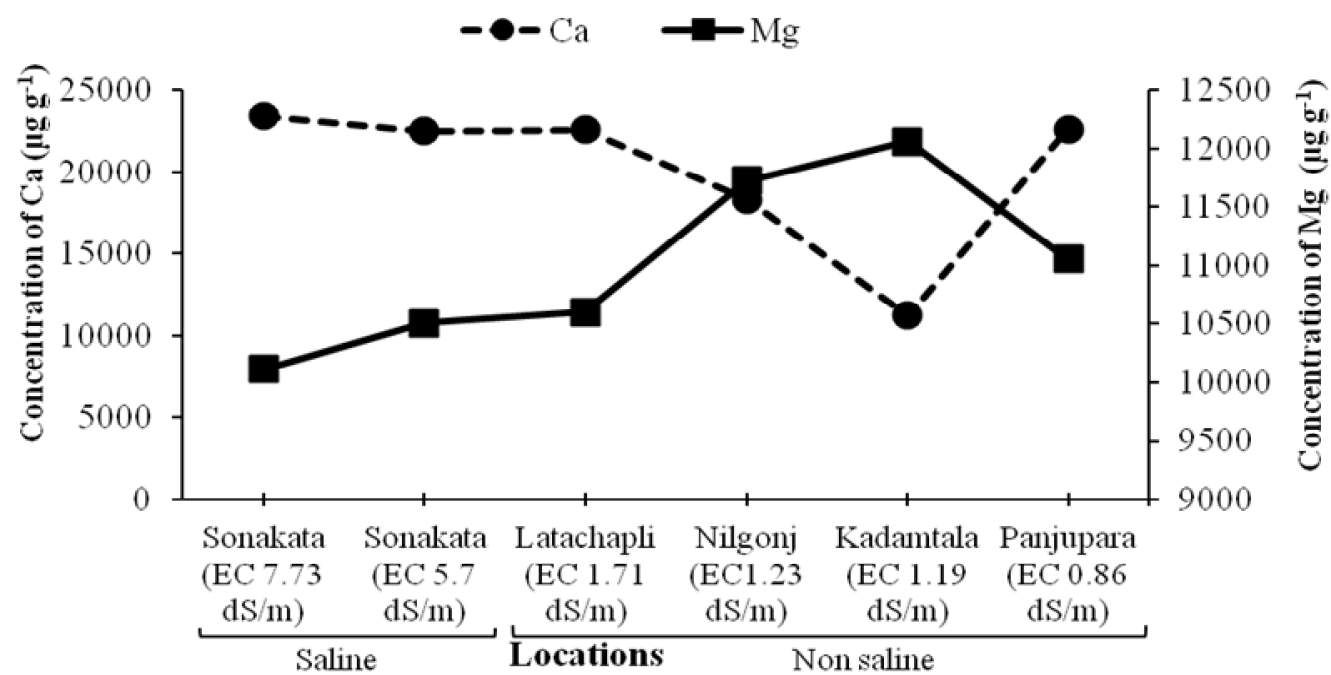

Figure 11. Concentration of $\mathrm{Ca}$ and $\mathrm{Mg}$ in bean at different EC levels of Barguna and Patuakhali districts.

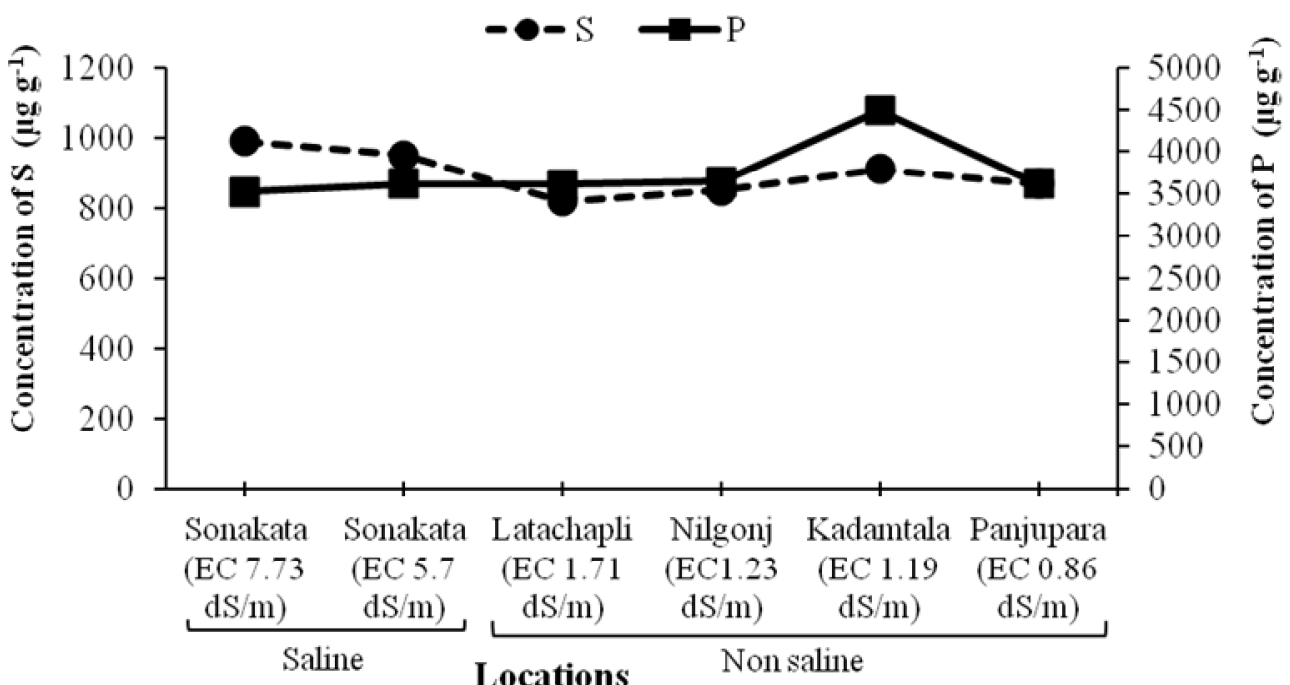

Figure 12. Concentration of $S$ and $P$ in bean at different $E C$ levels of Barguna and Patuakhali districts.

The Ca concentration in bean increased with the increase of soil EC due to higher Ca content of saline soil (1700 $\mathrm{g} \mathrm{g} \mathrm{g}^{-1}$ at $7.73 \mathrm{EC}$ ) (Figure 11 and Table 2). The $\mathrm{K}$ concentration in bean was randomly oscillated at the highest to lowest EC levels. Though the highest $\mathrm{K}$ content in bean was found at Sonakata (EC $7.73 \mathrm{dSm}^{-}{ }^{1}$ ), the highest soil K content was found at Kadamtala, Dumki, and Patuakhali (EC $1.19 \mathrm{dSm}^{-}{ }^{1}$ ) (Figure 10 and Table 2). This finding also has symmetry with 
that of Grattan and Grieve, (1999). They stated that the salinity increases the internal requirement of plants for a particular nutrient. The concentrations of $\mathrm{Mg}$ and $\mathrm{P}$ were higher at lower EC levels (Figure 11 and 12) but $\mathrm{S}$ concentration varied to a less extent at different EC levels (Figure 12). Therefore, uptake of S was not affected by the salinity.

\subsection{The mineral compositions $(\mathrm{P}, \mathrm{K}, \mathrm{Ca}, \mathrm{Mg}$ and $S$ status) of red amaranth}

The limits of $\mathrm{P}$ and $\mathrm{K}$ ranged from 4807.69 5128.2 and $94.0-143.0 \mu \mathrm{g} \mathrm{g}^{-1}$, respectively The maximum $\mathrm{P}$ and $\mathrm{K}$ was estimated in red amaranth at Kadamtala, Dumki , and Patuakhali (EC $1.19 \mathrm{dSm}^{-}{ }^{1}$ ) and Sonakata, Taltoly, and Barguna (EC $7.73 \mathrm{dSm}^{-}{ }^{1}$ ), respectively. The lowest $\mathrm{P}$ and $\mathrm{K}$ was present in red amaranth at Sonakata, Taltoly, and Barguna (EC $7.73 \mathrm{dSm}^{-}{ }^{1}$ ) and Latachapli, Kuakata and Patuakhali (EC 1.71 $\mathrm{dSm}^{-}{ }^{1}$ ), respectively (Figure 13 and 15). The limits of $\mathrm{Ca}, \mathrm{Mg}$ and $\mathrm{S}$ ranged from 15711.3 35278.4, 35006.4 - 51347.7 and 840.0 - 1190.0 $\mu \mathrm{g} \mathrm{g}^{-1}$, respectively. The maximum $\mathrm{Ca}, \mathrm{Mg}$ and $\mathrm{S}$ was estimated in red amaranth at Kadamtala, Dumki, and Patuakhali (EC $1.19 \mathrm{dSm}^{-1}$ ), Sonakata, Taltoly, and Barguna (EC $7.73 \mathrm{dSm}^{-1}$ ) and Nilganj, Khepupara, and Patuakhali (EC
$1.23 \mathrm{dSm}^{-1}$ ), respectively. The lowest $\mathrm{Ca}, \mathrm{Mg}$ and $\mathrm{S}$ was present at Sonakata, Taltoly, and Barguna (EC 7.73dSm- ${ }^{1}$ ), Kadamtala, Dumki, and Patuakhali (EC $1.19 \mathrm{dSm}^{-1}$ ) and Nisanbari, and Taltoly (EC $4.30 \mathrm{dSm}^{-1}$ ), respectively (Figure 14 and 15).

The accumulations of $\mathrm{K}, \mathrm{Mg}$ and $\mathrm{S}$ in red amaranth were highest at the highest EC level even though the soil concentration of these elements were not the highest at this level except S (Figure 13, 14 and Table 2). Studies revealed that yield components and growth parameters show differential responses to salinity stress. At low salinities root growth is often less affected, or sometimes even stimulated by salinity (Francois, 1984). Like this, higher salinity might have stimulated the uptake of $\mathrm{K}$ and $\mathrm{Mg}$ by red amaranth. The concentrations of $\mathrm{Ca}$ and $\mathrm{P}$ in red amaranth gradually decreased with the increase of EC level but these nutrients were estimated the highest in soil at the highest EC level. It confirms that unlike other vegetables, red amaranth cannot take up sufficient amount of these two particular nutrients from a nutrient rich soil if salinity is high (Figure 14, 15 and Table 2).

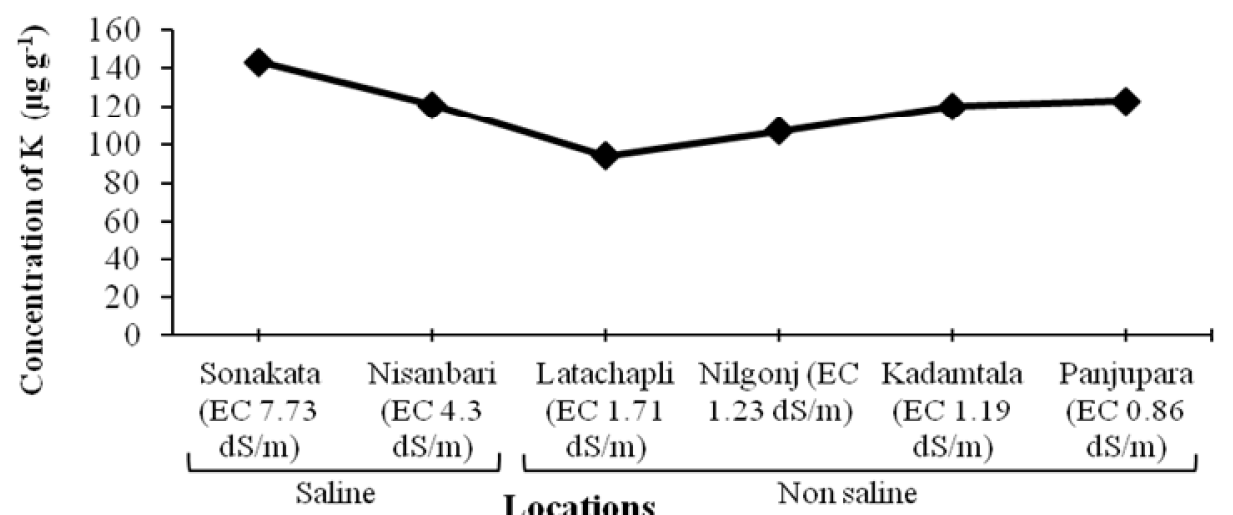

Figure 13. Concentration of $\mathrm{K}$ in red amaranth at different EC levels of Barguna and Patuakhali districts. 


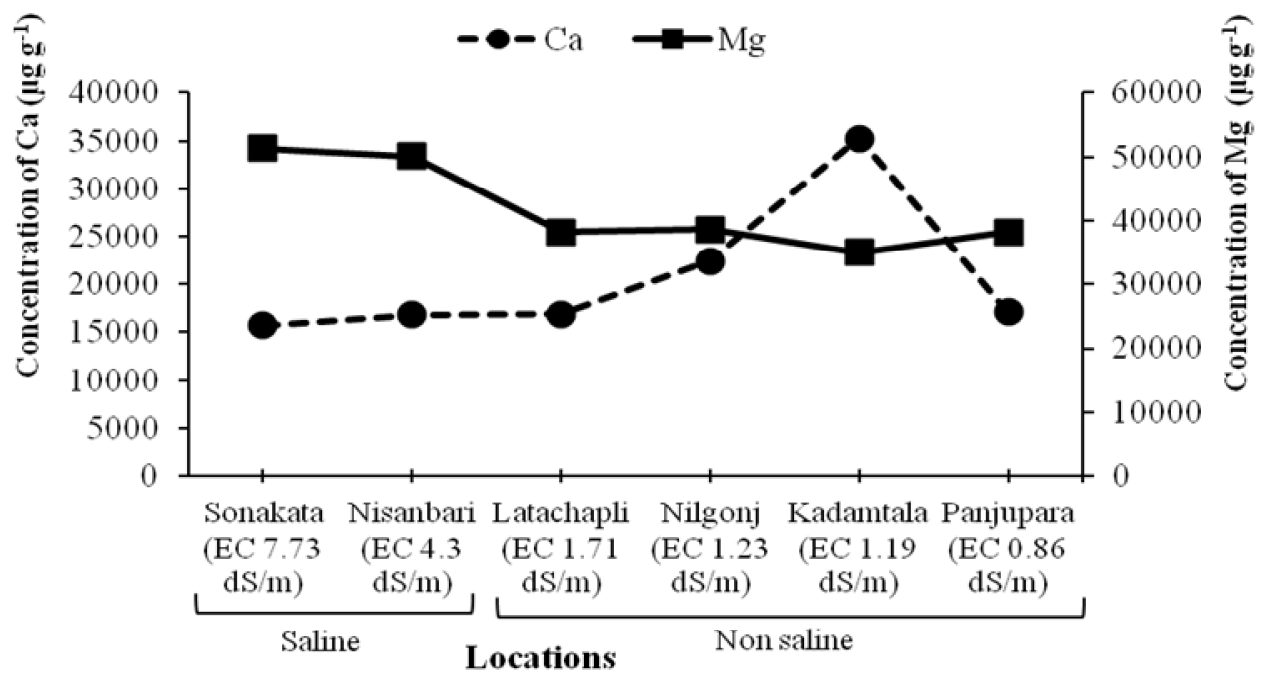

Figure 14. Concentration of $\mathrm{Ca}$ and $\mathrm{Mg}$ in red amaranth at different $\mathrm{EC}$ levels of Barguna and Patuakhali districts.

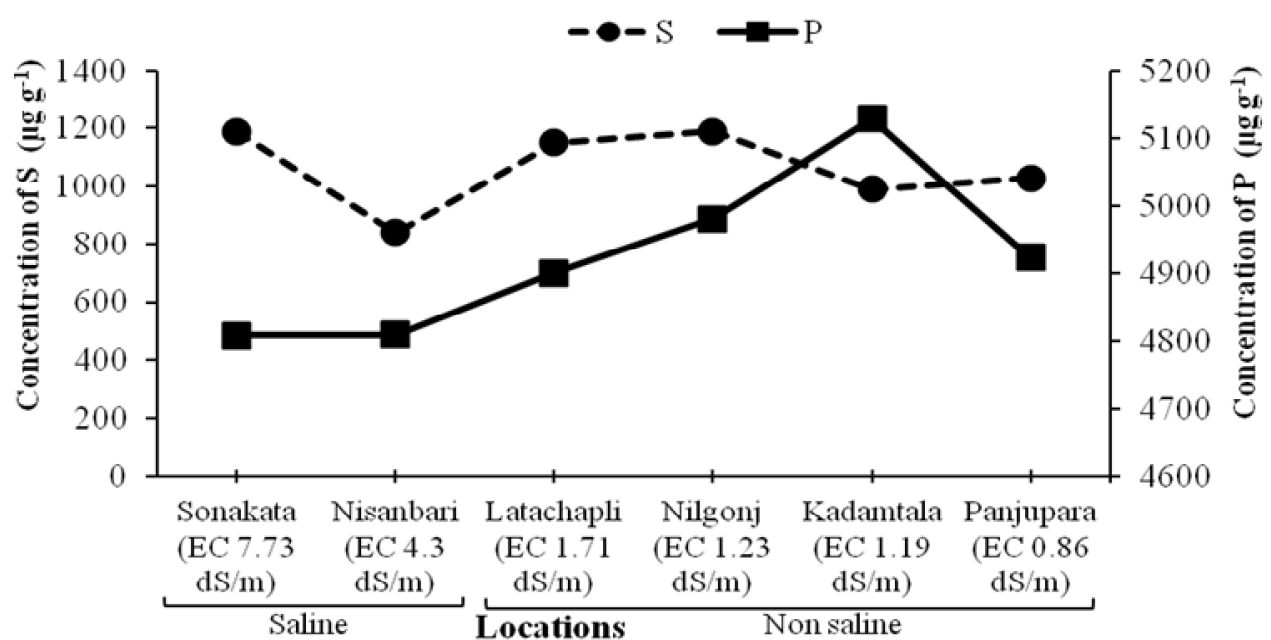

Figure 15. Concentration of $\mathrm{S}$ and $\mathrm{P}$ in red amaranth at different EC levels of Barguna and Patuakhali districts.

3.8 The mineral compositions $(\mathrm{P}, \mathrm{K}, \mathrm{Ca}, \mathrm{Mg}$ and S status) of spinach

The limits of $\mathrm{P}, \mathrm{K}, \mathrm{Ca}, \mathrm{Mg}$ and $\mathrm{S}$ ranged from 5128.2 - 5448.0, 77.0 -150.0, 12240 - 25631,

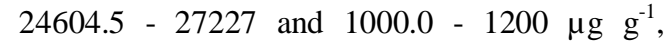
respectively. The maximum and minimum amount of $\mathrm{K}, \mathrm{Ca}$ and $\mathrm{Mg}$ were estimated in spinach at Panjupara, Kuakata, and Patuakhali (EC $0.86 \mathrm{dSm}^{-1}$ ) and Sonakata, Taltoli, and Barguna (EC $5.7 \mathrm{dSm}^{-1}$ ), respectively. The highest and lowest concentrations of $\mathrm{P}$ and $\mathrm{S}$ were observed at Nisanbari, Khepupara, and Patuakhali (EC $4.3 \mathrm{dSm}^{-1}$ ) and Sonakata, Taltoli, and Barguna (EC $5.7 \mathrm{dSm}^{-1}$ ), respectively. 
The $\mathrm{P}$ and $\mathrm{S}$ concentrations in spinach were randomly oscillated at different EC levels (Figure 18). This might be due to numerous salinity-nutrient interactions occurring at the vegetable fields that depend upon the salinity level and composition of salts, the crop species and a number of environmental factors (Grattan and Grieve, 1999). The concentrations of K, Ca and $\mathrm{Mg}$ decreased gradually with the increase of soil EC levels (Figure 16, 17 and Table 2). This infers that higher salinity condition of soil restricted the uptake of these nutrients by spinach. High salinity affects plants in several ways, viz. water stress, ion toxicity, nutritional disorders, oxidative stress, alteration of metabolic processes, membrane disorganization, reduction of cell division and expansion, genotoxicity (Hasegawa et al., 2000; Munns, 2002; Zhu, 2007). Together, these effects might have reduced the uptake of most of the nutrients by vegetables in this study.

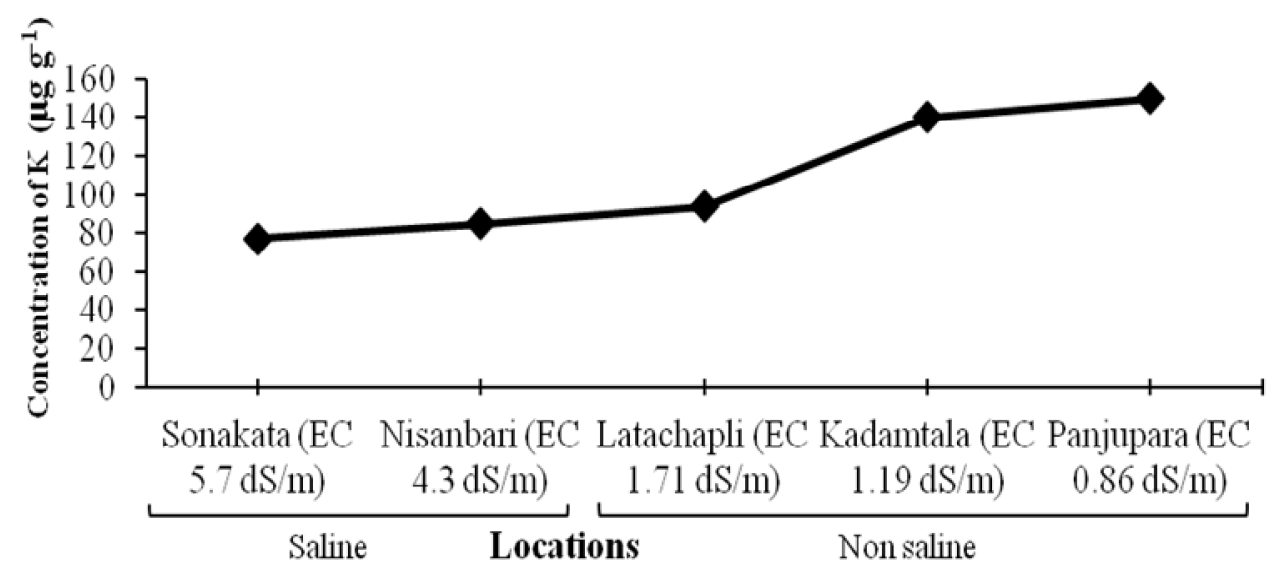

Figure 16. Concentration of $\mathrm{K}$ in spinach at different $\mathrm{EC}$ levels of Barguna and Patuakhali districts.

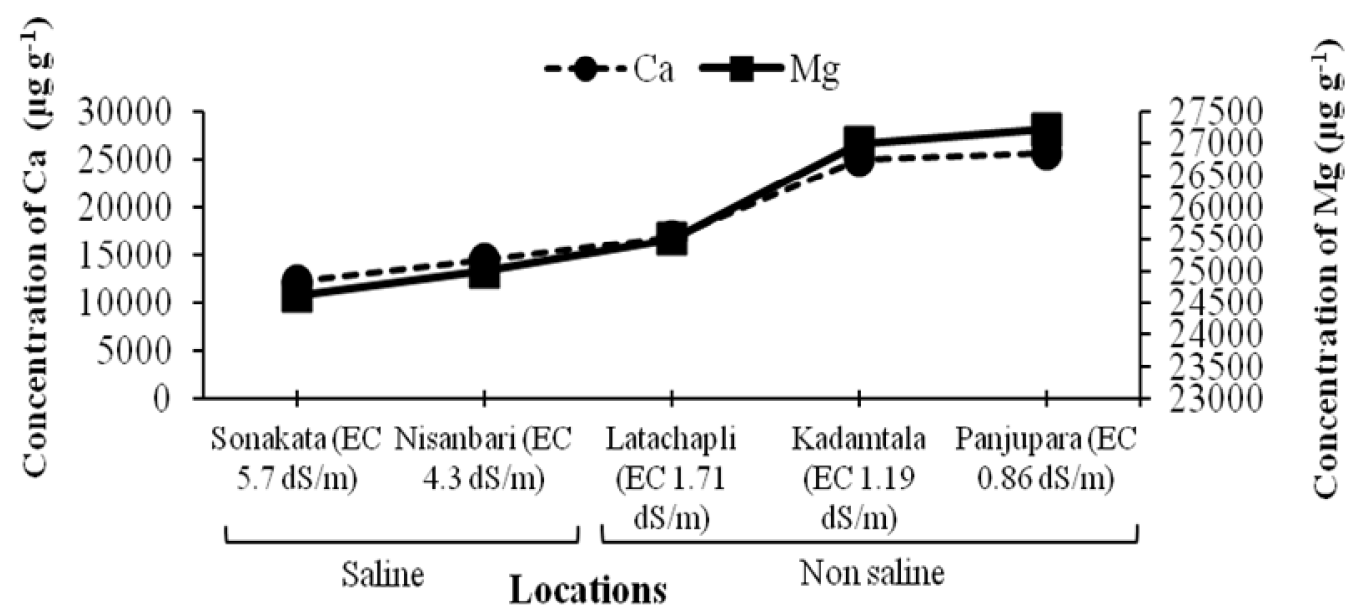

Figure 17. Concentration of $\mathrm{Ca}$ and $\mathrm{Mg}$ in spinach at different $\mathrm{EC}$ levels of Barguna and Patuakhali districts. 


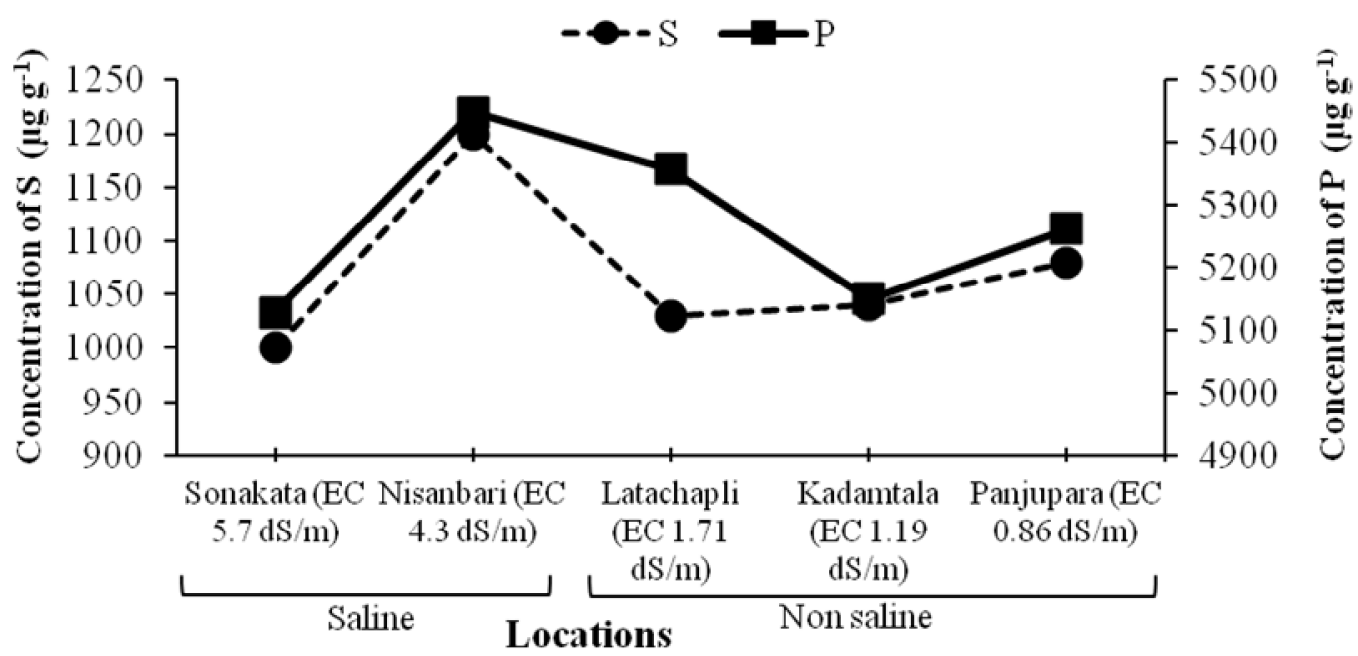

Figure 18. Concentration of $S$ and $P$ in spinach at different EC levels of Barguna and Patuakhali districts.

\section{Conclusions}

In the saline area, comparatively lower amounts of $\mathrm{P}, \mathrm{K}, \mathrm{Mg}, \mathrm{Ca}$ and $\mathrm{S}$ were found in most of the collected vegetables than those of the non-saline area. Accumulation of different mineral constituents in Bottle gourd, sweat gourd, radish, bean, red amaranth and spinach were remarkably affected by salinity. Moreover, increased soil nutrient status enhanced the uptake of some nutrients in bottle gourd leaf, radish leaf, bean and red amaranth in saline areas; hence, the salinity did not affect the accumulation of these minerals. Different vegetables can grow in saline area with sufficient mineral composition though the amounts of these minerals were found relatively low compared to that in non-saline soils. The mineral contents in most of the vegetables were also found within the average values. So, the vegetables of this study can be identified as moderate salinity tolerant crops (soil EC value up to7.79 $\mathrm{dSm}^{-1}$ ) and might be recommended to grow commercially in the tidal areas of Bangladesh.

\section{References}

Anderson JM., Ingram JSI. 1996. Tropical Soil Biology and Fertility a Handbook of Methods $2^{\text {nd }}$ edn. CAB International. Wallingford, U.K., 57-58 pp.

APHA (American Public Health Association). 2005. Standard Methods for the Examination of Water and Wastewater. $21^{\text {th }}$ edn., AWWA and WEF. Washington, USA. 1-30; 40-175 pp.

Bernstein L. 1962. Salt-affected soils and plants. In: Problems of the Arid Zones. Proceedings of the $18^{\text {th }}$ UNESCO Symposium, Paris, France, 139-174 pp.

Donald LS. 2003. Environmental Soil Chemistry. $2^{\text {nd }}$ edn. Academic Press, San Diego, California, USA.

Francois LE. 1984. Salinity effects on germination, growth, and yield of turnips. Horticultural Science, 19: 82-84. 
Ghosh AB., Bajaj JC., Hasan R., Singh D. 1983. Soil and Water Testing Methods. A Laboratory Manual, Division of Soil Science and Agricultural Chemistry, IARI, New Delhi - 110012, 1-45 pp.

Gomez KA., Gomez AA. 1984. Statistical Procedures for Agricultural Research. $2^{\text {nd }}$ edn., A Wiley Inter-Science Publication, New York, 28-443 pp.

Grattan SR., Grieve CM. 1994. Mineral nutrient acquisition and response by plants growth in saline environments. In: Pessarakli, M. (Ed.), Handbook of Plant and Crop Stress. Marcel Dekker, New York, 203-226 pp.

Grattan SR., Grieve CM. 1999. Salinity mineral nutrient relations in horticultural crops. Scientia Horticulturae, 78 : 127-157.

Hasegawa PM., Bressan RA., Zhu JK., Bohnert HJ. 2000. Plant cellular and molecular responses to high salinity. Annual Review of Plant Physiology and plant Molecular Biology, 51: 463-499.

Jackon ML. 1962. Soil Chemical Analysis. Constable and Co. Ltd. London, First Print.

Jackson ML. 1973. Soil Chemical Analysis. Prentice Hall of India Private Limited, New Delhi, 10-144 pp.

Marcelis LFM., Van Hooijdonk J. 1999. Effect of salinity on growth, water use and nutrient use in radish (Raphanus sativa L.). Plant Soil, 215:57-64.

Mor RP., Manchanda HR. 1992. Influence of phosphorus on the tolerance of table pea to chloride and sulfate salinity in a sandy soil. Arid Soil Research and Rehabilitation, 6: 41-52.

Munns R. 2002. Comparative physiology of salt and water stress. Plant, Cell and Environment, 25(2): 131-141.

Olsen SR., Cole CV., Watanable FS., Dean LA. 1954. Estimation of available phosphorus in soils by extraction with sodium bicarbonate. United States Department of Agriculture; Circular 939.
Page AL., Miller RH., Keeney DR. 1982. Methods of Soil Analysis, Part 2, Chemical and Microbiological Properties, American Society of Agronomy, Inc. Soil Science Society of America. Inc. Madison, Wisconsin, U.S.A., 252-255 pp.

Prakash RP., Sushil SK., Vinay RP., Vimal JP., Sunil MK. 2010. Impact of saline water stress on nutrient uptake and growth of cowpea. Brazilian Journal of Plant Physiology, 22 (1).

Rahman FMM., Mortuza MGG., Rahman MT., Rokonuzzaman M. 2008. Food security through homestead vegetable production in the smallholder agricultural improvement project (saip) area. Journal of Bangladesh Agricultural University, 6 (2): 261-269.

Rahman MM., Ahsan M. 2001. Salinity constraints and agricultural productivity in coastal saline area of Bangladesh. Resources in Bangladesh: Assessment and Utilization, 1-14 pp.

Shannon, Grieve. 1999. Tolerance of vegetable crops to salinity. Scientia Horticulturae. 78: 5-38.

Talbi ZO., Abdelly C., Debez A. 2011. Interactive effects of salinity and phosphorus availability on growth, water relation, nutritional status and photosynthetic activity of barley (Hordeum vulgare L.). Plant Biology, 13 (6): 872-880.

Tandon HLS. 1995. Methods of Analysis of Soils, Plants, Waters, Fertilizers and Organic Manures. Fertilizer Development and Consultation Organisation, New Delhi, India.

Tanji KK. 1990. Agricultural Salinity Assessment and Management. American Society of Civil Engineers, New York, N.Y.

Zhu JK. 2007. Plant Salt Stress. Encyclopaedia of Life Sciences. John Wiley and Sons, Ltd., UK. 